\title{
Determinants of Public Sector Innovation: The Example of Capacity Development in Public Procurement
}

\author{
Nils Otter \\ Carinthia University of Applied Sciences, Villach, Austria \\ n.otter@fh-kaernten.at \\ Mike Weber \\ Fraunhofer Institute FOKUS, Berlin, Germany \\ mike.weber@fokus.fraunhofer.de
}

\section{ABSTRACT}

The Triple-Helix-Model stresses the idea that a successful national system of innovation ought to incorporate the complexity of three social subsystems: private sector economy, governmental system and science. Following the insight that the state and its agencies are important players in any system of innovation, we take a closer look at the innovative action in the public sphere. Therefore, we propose an analytical tool that allows a more detailed explanation of relevant determinants of innovative behaviour: (1) property rights, (2) capabilities, and (3) motivation. In order to show the relevance of these determinants, we tested the plausibility of our theoretical tool against the topic of public procurement of innovation. Five hypotheses were derived and then tested empirically by using a data set about German public procurement practice. Our linear regression model provides evidence for the hypotheses that framework conditions, special training, and motivation of procurement staff play a central role in demand-driven innovation of the public sector.

Keywords: innovation, Triple-Helix approach, public sector economics, capacity building, procurement of innovation

JEL:B52, H 83, O31, P48

\section{Introduction}

While the connection between innovation, growth and social development is usually examined with relation to private sector enterprises (Audretsch et al. 2006), in recent years the innovation capabilities of other social subsystems have moved into the point of view. Moreover, the public sector and public management capabilities can be seen as an important part of the economic development of regions or countries. As a reference, one can state explicitly 
the literature on "varieties of capitalism" (see Hall \& Soskice, 2001; Elsner \& Hanappi, 2008) as well as studies that use a "National Business Systems" approach (Nelson, 1993; Lundvall, 1999). Insofar, the efficiency of the public sector can be interpreted as an important location factor in a global competitive process as well (e.g. Kristensen \& Lilja, 2011). Nevertheless, these recent developments are only partly reflected in the scope of the literature on innovation theory (Greenhalgh \& Rogers, 2010; Daskalakis, 2010). In order to do so, we propose in this paper a theoretical model that is applicable to the market sector as well as to the public sector.

The paper is structured as follows: We briefly introduce research on innovation that is based on the Triple-Helix-Model and present our approach to explain innovative behaviour. Following the early work of Röpke (1977), we use three kinds of variables as our determinants of innovative action: property rights, capabilities and motivation. Based on this theoretical background we develop further considerations with regard to the possibilities and problems of innovative action that might (or might not) take place in the sphere of bureaucracy (2). The focus will be on innovation in the public sphere and the field of public procurement has been chosen as a principal example to demonstrate the workability of our analytical tool (3-5). The paper ends with a conclusion (6), showing that the results for the innovation system might be substantial: If the relevant players are not allowed to innovate, public managers do not have the capabilities to innovate, or are not motivated to innovate, then the structural coupling between government and the economic system will not succeed in the long run. As a result, there will be negative consequences for the national system of innovation, e.g. the ability of a society to develop by innovative advances.

\section{Innovation Theory and Public Administration}

In the economic literature on innovation, one can distinguish at least two different branches of theory: While in industrial economics (or endogenous growth theory) particularly hypotheses about the macroeconomic effects of innovation are picked out as a central theme, the branch of evolutionary economics analyses the endogenous causes of the innovation process (for a broad survey see Fagerberg, Moweira \& Nelson, 2006). Consequently, the role as well as typical characteristics of entrepreneurship can be seen as the core of this line of theoretical reasoning (Röpke, 2002; Fagerberg, 2003; Fagerberg, 2006). The latter approach is used here because it seems to be much broader in its applicability, especially with regard to topics like the system of public administration. In our view, one should deal more thoroughly with the possibilities as well as restrictions of innovative behaviour in the nonprofit sectors (public management, non-profit organisations) of an economy (Zimmermann et al., 1998). In other words, there is a need to strengthen the innovative capabilities of the state. This thesis has been furthermore stressed by work on the interdisciplinary nature of innovation, e.g. Goto (2000, p. 104): 
"The national innovation system essentially consists of three sectors: industry, universities, and the government, with each sector interacting with the others, while at the same time playing its own role". One of the models that can be used to describe the interactions between different societal systems has been labelled "Triple-Helix-Model" (Etzkowitz \& Leydesdorff, 2000) which is explicitly based on the complex nature and interactions between the three subsystems economy, science and state.

\subsection{The Triple-Helix-Approach and Systems of Innovation}

Against this background of innovation theory in the literature, it should be obvious that the national system of innovation is somehow a complex building with one system interacting with the other subsystems (Leydesdorff, 2010, 5ff.). Therefore, the Triple-Helix-Model is used as a metaphor for the fundamental relationships between the three social subsystems economics, science and government. On the one hand, the characteristics of these corresponding networks are defined. On the other hand, the differences regarding the incentive structure and the flexibility of transformation are stressed. The aim is mainly to describe and explain structural developments of a knowledge-based economy. In application to the case of public administration, we find more hierarchical structures of decision, different ways to generate and transfer knowledge as well as other incentive systems to the staff.

In addition, of course, the public sector influences both other subsystems by different means, e.g. legislation and regulation. The model is therefore closely connected to the Systems of Innovation (SI) approach, which can be defined as "all important economic, social, political, organizational, and other factors that influence the development, diffusion, and use of innovations" (Edquist, 1997, p. 14). However, as Edquist $(2001$, p. 3) in a discussion about SI has already remarked, there has been a weakness of the SI approach since „it lacks a 'theoretical' component about the role of the state. This is an important neglect, since the state and its agencies are obviously important determinants of innovation in any SI".

As a first step, it seems plausible to discuss the role of the state by looking at the mechanisms used to influence the innovation system, e.g. through public innovation policy. In general, innovation policy can be described as all public action that has an impact on technical change or influences other kinds of innovations (Edquist, 2002). On the supply side, this mainly means science\&technology policy, e.g. the public provision of basic research as a public good. But innovation policy goes beyond by including elements of research\&development, technology and infrastructure policy as well as regional policy and education policy. In consequence, innovation policy can influence innovation just as much from the demand side. In this respect, especially public procurement is of importance. Therefore, the case study that will follow is related to the field of public procurements as an instrument. 
Furthermore, Edquist (2001, p. 10f.) suggests that function or determinants of innovation should be given more emphasis, because such work would be an important attempt to raise the theoretical status of the SI approach. Thus, explanatory work should include a specification of the relative importance of determinants as well as the relations between them, which mightvary between certain kinds of innovation, e.g. process or product innovation. In short, he expects knowledge progress by integrating "conceptual and theoretical work with empirical studies in an effort to identify determinants". This path of research is followed by Edquist and Zabala-Ihurriagagoitia (2012), who categorize public procurement for innovation along three dimensions: first, the user of the purchased good; second, the character of the procurement process; and third, the cooperative or non-cooperative nature of the process. In accordance to this, our proposed approach can be interpreted as an additional framework that allows to obtain testable statements. And it will be accomplished by an empirical analysis in the field of public procurement as well.

Another way to classify the role of the state has been given by Greenhalgh and Rogers (2010, p. 103f.), who focus on the topic of public action. They assume that the most relevant topics with regard to innovative activities will be intellectual Property Rights (patent law, product permissions), tax policy (enterprise taxation, depreciation possibilities, establishment promotion), competition policy (regulation of monopolies, merger control), public subsidies for scientific research, standardisation, and public procurement. However, since every listed topic above involves different network agents as well as incentive structures, it seems to be necessary to discuss them separately. Yet, this is the third reason why we will concentrate on the field of public procurement in our case study. But initially, we have to describe our conceptual approach for the analysis of the determinants of innovative behaviour.

\subsection{Determinants of Innovative Behaviour}

Our general explanation of innovative behaviour, either on the individual or organisational level, uses three measurable variables: the structure and incentives of property rights, the degree of individual capabilities and knowledge (competences) and, last but not least, motivational aspects. In the concrete, these determinants of innovative behaviour can be understood as follows:

1. Property rights: In short, under this heading one can assume all formal and informal rules, which limit the acting of individuals or organisations. They can be further divided up in property rights on the level of the economy, the level of organisation as well as on the level of societies, e.g. cultural values (Röpke, 1983, p. 122ff.). In particular, for the field of public administration it might be of serious concern that innovation in the public sphere is often not very welcome. Instead, there is a "rule 
of tradition" that will be altered by new ways of action (Picot \& Schneider, 1988, 99ff.). Alternatively, to put this in pure economic terms, the resulting benefits for all parties involved will be changed by innovation, resulting in new distribution patterns of economic resources. In fact, some political interest groups will suffer from innovation externalities, which is one of the reasons why innovative solutions have much higher transaction costs than routine actions. However, it should be noted in this context that there is a controversial discussion about the role of property rights in creating incentives to innovate. To put it in a nutshell, if patent policies foster the diffusion of knowledge and stimulate market entry and competition, then there might be social benefits from stronger incentives to innovate. On the contrary, assigning strong intellectual property rights to early inventors may discourage innovation, e.g. due to litigation risks of later generations of inventors (see Boldrin \& Levine, 2013; Moser, 2013). Recently, the growing prominence of patent aggregators called "Intellectual Ventures has sparked heated debates about the economic role played by intermediaries in the patent market and their effects on innovation" (Hagiu \& Yoffie, 2013, p. 46).

2. Capabilities (competences): One of the preconditions for discoveries or the implementation of innovation can be seen in the cognitive capabilities of an individual. In abstract terms: "creativity proves to be the outstanding component of the innovation process, since it affects the decision and action logic of the individual strongly" (Brandstätter, 1992, p. 98ff., own translation). With regard to this variable the genetic equipment as well as the level of education and training plays an important role.

3. Motivation: Even if innovative action is allowed by property rights and the staff has the required cognitive abilities, then there still might be a last barrier to innovation: Individuals can simply not be motivated enough to leave a "life in routines" for innovative new solutions. We base these considerations on the so-called "achievement motivation theory" developed by McClelland and Heckhausen. Its core hypothesis can be summarized as follows: human beings are mainly motivated by personal achievements; ideally, they choose those tasks where the degree of difficulty is somehow "in the middle range", meaning that the result of action can be attributed to one's own achievements (McClelland \& Heckhausen, 1980). Of course, the motivation of individuals can be affected positively or negatively by the usage of either extrinsic or intrinsic incentives.

As is shown by figure 1, all three variables are interconnected to each other and work as filter for innovative behaviour. 
Figure 1: Explanation of innovative behaviour

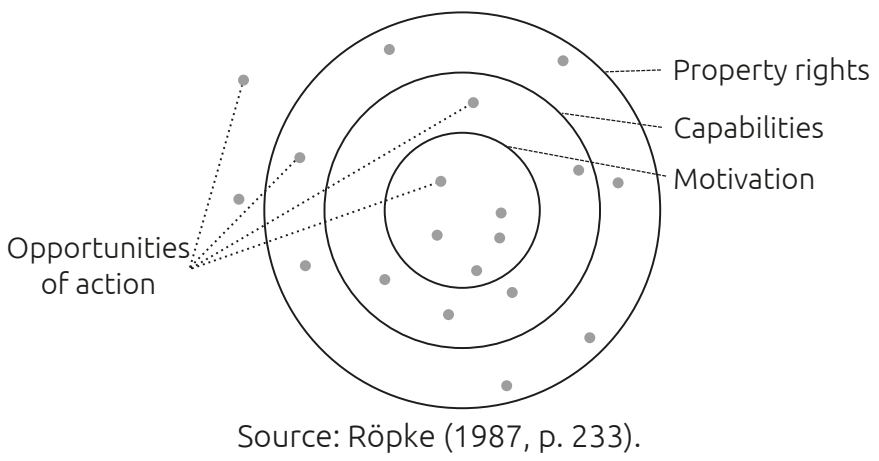

Based on this set of variables, one will be able to formulate hypothesis with regard to the consequences of organisational and political reform or to determine the window of opportunity to innovate inside public administration. As an analytical tool, it might help in showing the important consequences for the functioning of the innovation system. If the personnel in public administration is not allowed or not able or not motivated to innovate, then the structural connection to the other sectors (science and economy) will not succeed in the long term. This problem might be eliminated by other actors of the national system of innovation, at least as long as these actors have the necessary opportunities of action at their hand.

Next, we use this theoretical framework to examine whether the political staff or respectively the public administration will have the necessary degree of freedom for innovative behaviour. Therefore, we first take a look at the legal restrictions for innovative policies. Followed by a discussion of the way official staff is likely to act as an "intrapreneur" in his or her organisation. Finally, ways for using the huge amount of "tacit knowledge" incorporated in public administration for the production of public goods will be explained. The strength of our proposed framework can be seen in the fact that we will be able to analyse innovative behaviour on the micro level by means of the public staff as well as on the macro level by property rights set by the national system of innovation. In order to show the workability of our theoretical considerations, we now apply our model to the field of public procurement in Germany.

\section{Selection of Case Analysis: Public Procurement}

Public procurement has a huge potential for innovative behaviour of public authorities. In 2008', Eurostat estimated a total procurement volume for the EU27 of $17.3 \%$ of GDP (equivalent to 2.16 billion $€$ ), a number showing that the public sector has a significant market power. Regarding single product

1 Own calculations based on Eurostat (2010). The estimations tend to exceed the actual procurement volume, since, for example, spending by the social insurance system is taken into account (Audet, 2002; Weber, 2010). 
groups respectively sectors such as ICT, the public demand reaches such a large proportion that further market development can be emanated from this major impetus. Similarly, considerable impetus to public institutions themselves can be emanated from purchasing innovative products and services. Just to give an illustrative example, it can be referenced to the introduction of workflow management software and document management systems, which can deeply interfere in the procedures of the concerned institution (Lorenz et al., $2009,39 f$.$) . With reference to the interaction between impetus to the public$ institutions through the purchase of innovative solutions on the one hand, and the innovation-promoting effect on the suppliers by a challenging public demand on the other hand, the second aspect is gaining more and more political importance. Therefore, public procurement has been increasingly granted with the suitability as an instrument of innovation-oriented demand policies (Edler et al., 2005; European Commission, 2007a, 2007b; Edquist et al., 2000; Georghiou et. al., 2010). By way of example, one can refer to procurement practices in the UK (Hughes et al., 2011), even on the local level (see Uyarra, 2010), or the initiative of the European commission under Horizon 2020 (European Commission, 2011).

Furthermore, especially in overcoming the so-called "Valley of Death" this kind of demand for novel solutions can play an important role. The Valley of Death is a common term in the entrepreneurship world, relating to the serious challenge of covering the negative cash flow in the early stages of a new venture, before the innovation (service or product) is generating revenue from real customers (see Osawa \& Miyazaki, 2006; House of Commons, 2013). Beside this general difficulty of start-ups, Beard et al. (2009) have argued that the Valley of Death occurs especially in the presence of 'non-economic' investments, foremost with regard to government expenditures on basic research. Public Procurement might close the gap between public funded research in early stages and private investment decisions at later stages of the innovation process. The challenging needs of the public sector can directly lead to the development of novel solutions and to the setup of production capacities. At a sufficient expectation of benefit, the public sector can take considerable risks in this context, e.g. maintaining start-up's or specialized suppliers.

The public procurement of innovation can be regarded as an exemplary case for innovation activities in the Triple-Helix-Model: With regard to purchasing, the given relationship between government and economy is expanded by a research and development aspect. All three social sub-systems interact with each other in such projects, whereby science and economy cope with their specific function of production of knowledge or goods and services respectively. Moreover, due to this constellation, there will arise new challenges for public administration. The purchasing of innovation requires actions with a strong innovation orientation, which is often in tension to the legislative framework regulating procurement. Here, innovation orientation 
is often accompanied by the innovative handling of procedures (Lorenz et al., 2009, pp. 64-75). Given these interactions, innovative behaviour is understood, in terms of the theoretical approach developed above, as an innovative processing method, as innovation-oriented procurement practice and simply as purchasing innovation.

Thus, the public purchase involves the potential for considerable innovation impetus to public administration, economy and science. Given this vast potential, the inventory of the innovation orientation and the innovation degree of the German federal procurement practice is sobering. Regarding the procurement strategy, promoting innovation plays only a subordinate role and, instead of comprehensive economic criteria, the purchasing price dominates as a key award criterion for public contracts. This makes an awarding of innovative solutions unlikely (Weber, 2009). A fact, that needs to be explained in order to derive ways of its evaluation and overcoming.

\section{Hypotheses about Determinants of Public Sector Innovation in Public Purchasing}

In order to explain the above stated gap between a potential and an empirical use of public procurement as a tool for demand-driven innovation, we now consider the three variables of innovative behaviour in more detail. In order to do so, we first derive some hypotheses from our analytical tool that will then be tested in the next chapter by using our empirical data set from German public procurement.

\subsection{Property Rights}

Initially, the function of property rights, defined as an opportunity space for action, seems to be simple: Public authorities can define their requirements and the solution they need to meet their demands without constraints. In principle, the property rights are fully held by public authorities, while enterprises get the chance to adjust their offer to the requirements described in the calls for tenders. However, in reality we can observe constraints on different levels of the procurement process, which hinder public authorities to make use of their rights. In short, two different types of constraining factors can be distinguished: The internal structure of public authorities and external constraints respectively the way public servants deal with these constraints.

First, public authorities cannot be dealt with "as if" there is only one single unique entity. Many different stakeholders in the organisation try to achieve different and partly contradictory goals (Edler et al., 2005, p. 40ff.). The political level and the level of strategic management are two powerful players in this game. If politics and management differ in their aims related to public procurement, different priorities of departments should be taken into account as well. For example, while the department which finances the project might only be interested in a low initial price, the department which has to deal with 
the maintenance of the procured product (e.g. a new building) might focus on initially more expensive and probably more innovative solutions to lower costs in the long run. A clear strategic priority and the political will to foster innovation is essential to overcome these conflicting interests. Thus, our first hypothesis with regard to property rights reads as follows:

H1: An explicit strategy and political support enable procurer to strengthen innovation orientation in public procurement.

Second, the most powerful external constraint is the legal framework the purchasing agencies have to deal with. Many public procurers experience that the density of procurement regulation inevitably leads to legal mistakes in nearly any process. This external constraint, which does not influence the objective of the purchasing process directly, produces an error risk, which causes risk-avoiding behaviour of civil servants (Otter et al., 2007, p. 100). In sum, internal structure and external constraints favour a conservative procurement practice. On this organisational and legal background, success is measured by absence of mistakes and not by procuring innovative solutions: $\mathrm{H} 2$ : The willingness to take risk is required to make use of instruments of innovation orientation.

\subsection{Capabilities, Competences, Capacities}

Both, conflicting interests and failure risks signify the need for highly skilled civil servants. Employees who want to purchase innovative solutions have to deal with legal, organisational, and technical risks (European Commission 2010) in a convenient and convincing way. To cope with all these challenges two aspects have be taken into consideration: education and training for the staff and a professionalization of procuring agencies. In many cases procurement is not part of the key competences and functions of public agencies. As a consequence purchasing is executed as side job by civil servants without special training (Lorenz et al. 2009, 57). It can be expected that this absence of special training will have an impact on the innovative behaviour:

H3: Skilled and especially trained procurement staff leads to more innovative behaviour in public procurement.

Another way to cope with the broad range of requirements is the outsourcing of the task to specialised units. Thus:

H4: A centralised structure of procurement with specialised procurement units leads to more innovative behaviour in public procurement.

\subsection{Motivation}

Despite some hindering framework conditions, many cases of public procurement of innovation procedures can be observed in practice. In many of these cases, highly motivated civil servants guarantee the achievement of these purchasing projects. These employees can be described as intrapreneurs 
who drive forward the organisation they are working for. However, these cases cannot conceal the fact that administrative culture in general favours acting in accordance with the law or other organisational routines. Fault tolerance, learning by errors, and giving something new a chance are by no means generic elements of administrative culture (Krone, 2003). In addition, public authorities offer little incentives to foster motivation of their employees. Thus, motivation is expected to be a critical factor for innovative behaviour of public agencies:

H5: Motivation of procurement staff has a strong impact on innovative behaviour in public agencies procurement.

\section{Empirical Investigation}

Our data allow the empirical testing of the above stated hypotheses for the German Case. The next paragraph will deliver a description of the database as well as the operationalization of the theoretical constructs. Then, the findings of the statistical model are presented, followed by a short discussion of some mayor constraints of the analysis.

\subsection{Database and Operationalization of Theoretical Constructs}

To get an empirical inside of German procurement agencies we use data from a survey conducted in 2009. The survey was part of the research project "Purchasing State" which was partly funded by the German Federal Ministry of Education and Research (Lorenz et al., 2009). The survey realised 265 responses of all types of German procurement agencies, which corresponds to a response rate of $11.5 \%$. The questionnaire covered a wide range of different aspects with relevance to innovation-orientation. For hypotheses testing six theoretical concepts have to be measured (Table 1).

Table 1: Operationalization of theoretical concepts

\begin{tabular}{|c|c|}
\hline Variable & Measurement concept \\
\hline \multicolumn{2}{|r|}{ Property rights } \\
\hline $\begin{array}{l}\text { Innovation-friendly } \\
\text { framework conditions }\end{array}$ & $\begin{array}{l}\text { Strategic orientation in favour of innovation procurement in contradiction to } \\
\text { initial costs and political influence on procurement practises }\end{array}$ \\
\hline Encouraged risk-taking & $\begin{array}{l}\text { Share of new suppliers and share of more sophisticated award criteria than } \\
\text { the initial prices }\end{array}$ \\
\hline \multicolumn{2}{|r|}{ Capabilities, competences, capacities } \\
\hline Special training & Existence of special trainings of procurement staff \\
\hline Centralised structure & $\begin{array}{l}\text { Procurement only by centralised units and probably by external service } \\
\text { provider }\end{array}$ \\
\hline \multicolumn{2}{|r|}{ Motivation } \\
\hline $\begin{array}{l}\text { Motivation of } \\
\text { procurement staff }\end{array}$ & $\begin{array}{l}\text { Optimistic assessment of purchasing instruments for fostering innovation in } \\
\text { public procurement }\end{array}$ \\
\hline \multicolumn{2}{|r|}{ Innovative behaviour } \\
\hline $\begin{array}{l}\text { Innovation-orientation of } \\
\text { procurement practices }\end{array}$ & $\begin{array}{l}\text { Participation of internal knowledge carriers and stakeholders, innovation as } \\
\text { aim of negotiations, innovation-friendly procedural aspects, innovation-related } \\
\text { aspects in technical specifications, internal and external cooperation, use of } \\
\text { various way of market observation }\end{array}$ \\
\hline
\end{tabular}




\subsection{Statistical Modelling}

The distribution of the dependent variable allows the application of linear regression analyses. The independent variables are statistically independent and the statistic of residuals does not show any indication of violating distribution assumptions. The model is printed in Table 2.

Table 2: Linear regression on innovation-orientation

\begin{tabular}{|l|c|c|}
\hline & Coefficient (beta) & \\
\hline Framework & 0.174 & * \\
\hline Risk-taking & 0.002 & \\
\hline Training & 0.170 & * \\
\hline Structure & 0.029 & \\
\hline Motivation & 0.340 & * \\
\hline R $^{2}$ adjusted & 0.206 & $*$ \\
\hline $\begin{array}{l}\text { 202 valid cases } \\
\text { Significance: *99\% }\end{array}$ & & \\
\hline
\end{tabular}

The model shows medium effect of framework conditions and specialised training on innovation-orientation in public procurement and a strong effect of motivation. All three effects are significant on the $99 \%$-level. Encouraged risk-taking and a centralised structure have no significant effect on the depended variable. The whole model fits with an adjusted $\mathrm{R}^{2}$ of 0.2 well and is although highly significant.

The statistical model provides empirical evidence for the hypotheses 1, 3 and 5. Framework conditions, special training, and motivation of procurement staff have significant positive impact on innovative behaviour in public procurement. In contrast, we have to reject hypotheses 2 and 4 at this stage of analysis. Neither for risk-taking nor for the organisational structure can we observe a significant impact. Nevertheless, our results of the case study stress the importance of all three determinants of innovative behaviour. Property rights, capabilities, and motivation influence the way public authorities fulfil their duties.

\subsection{Constraints}

Although the above findings suggest that all three aspects might determine innovative behaviour, attention must also be drawn to some restriction of the empirical model. First, the empirical investigation suffers from those constraints which are typical for a secondary analysis: The survey might probably be biased towards a positive selection of cases. It seems to be plausible that large authorities with a more professionalized procurement structure had answered more likely. In addition, the operationalization of theoretical concepts is limited to the indicators surveyed. This might compromise the validity of the empirical concepts to some extent, e.g. especially the indicator for motivation seems to be critical in this context. 
Probably this indicator is just too close to the innovation indicator. Thus, the effect might be overestimated.

Second, the analysis offers only a rough modelling of the theoretical considerations. On the one hand the determinants of innovative behaviour are not logically independent. To some extent property rights are a precondition for the effectiveness of capabilities and motivation. On the other hand the model ends with the explanation of innovative action. Innovative behaviour is one important determinant of innovative output, but it is not the only one. A more complex modelling can help to overcome these constraints. Such a model has to consider interaction effects as well as control variables, like the type of procuring organisation and procured products and services. To model these interaction effects in a second iteration, one has to specify the theoretical considerations in more detail. Additionally a two steps regression analysis can show the effect of innovative behaviour and innovation impact.

\section{Conclusion}

Public procurement of innovation can be seen as innovative behaviour in two ways. On the one hand, efficient procedures offer significant saving potential and effective targeting of public needs improve quality of purchased solutions. On the other hand public procurement levers innovative behaviour in the private sector. The analytical framework developed here offers an opportunity to get a better understanding of the fact that practices in procuring innovative solution are still subject to different restrictions. The analysis was based on three determinants of innovative behaviour: property rights, competencies, and motivation. In order to show the relevance of our proposed determinants, we tested the plausibility of our theoretical tool against the topic of public procurement of innovation. Therefore, five hypotheses were derived in connection to the process of public procurement and then tested empirically by using a data set from German public procurement practice. Our linear regressions model provides evidence for the hypotheses that framework conditions, special training, and motivation of procurement staff play a central role in demand-driven innovation of the public sector. In contrast to this, our hypotheses about risk-taking as well as organisational structure were rejected. In sum, hindering constraints inside and outside public agencies, a lack of motivating elements in administrative culture, and the antagonism between the low level of public procurement training and the complexity of innovation-oriented procurement practices are important barriers to make procurement an instrument to foster innovation of public authorities as well as of private enterprises.

But the determinants cannot only be used to describe the main problems, they might as well serve as a starting point to overcome these barriers. Likewise, the identified obstacles describe the areas of interest which should be modified to make use of public procurement as a broader policy instrument. 
Many initiatives especially on the European level can be observed to facilitate procurement of innovative solution by public agencies. To name a few, the modernisation of European procurement regulation has to be mentioned as well as subsidies for dealing with risks in innovation-oriented procurement procedures. Thus, in medium terms procurement professionals might get the full set of property rights for buying more innovative solutions. In the meanwhile, the awareness of the positive impact of public procurement of innovation on the solution of great societal challenges like climate change and financial crisis is rising. This growing awareness might become an important source for the motivation of procurement professionals. Many additional trends foster public procurement of innovation by additional property rights and by motivating civil servants.

In the area of capabilities, the solution seems to be quite simple. More and better-trained procurement staff might lead to a boost for buying innovative solutions. Keeping budget restrictions in mind, certain functional equivalents might be needed. Empirical evidence can be found that three aspects can significantly contribute to enable civil servants to buy innovative products:

1. Modernisation of purchasing procedures: electronic support for purchasing stuff might help to avoid mistakes. Suitable electronic government solutions are required to implement e-procurement systems (Lorenz et al. 2009, p. 71f.).

2. Open innovation platforms: cooperation between different departments and external actors, especially potential suppliers, are crucial for the success of innovation projects. Electronic platforms can provide a medium for the interaction between relevant partners and can help civil servants to gather required technical and market information (ICLEl et al., 2015).

3. Reference to standards: referencing standards in technical specification allows the usage of codified and accepted knowledge about technical details. Thus, standards offer an affordable and easy way to consider quality aspects (Blind \& Weber, 2012).

From our point of view, it is crucial to consider first the options for action in public authority to analyse the impacts on the other subsystems. Innovative action might even lead to a "creative destruction" of the rule of traditions in socio-economic institutions in the sense of Schumpeter (Otter, 2009). Given public budget restrictions, only the recombination of existing resources might cause impulses to innovativeness and growth. In this sense, innovative and innovation-oriented public authorities do not only guarantee the efficiency of their services. Instead, they can contribute to a dynamic innovation policy, which helps to overcome the great challenges. Without additional resources and only by recombining existing assets, significant efficiency growth and impulses for innovation in economy and science can be achieved. Thereby electronic support and use of existing knowledge might facilitate the building 
of required capacities. Thus, enabling innovation in public authorities becomes one key factor to respond to the current societal challenges.

Prof. Nils Otter, PhD, is a tenured professor of economics at the Carinthia University of Applied Sciences in Villach. Prior he worked for the state chancellery of Saxony-Anhalt and as senior researcher at the German Institute of Public Administration in Speyer. He received his Ph.D. and diploma in economics at Philipps-University Marburg. His research focus is on Schumpeterian economics, innovation theory and long business cycles.

Mike Weber, PhD, finished his studies in sociology at the University of Bielefeld and received his PhD with a thesis about mechanisms of knowledge transfer in start-up support at the University of Administrative Sciences Speyer. He conducted various empirical research projects focussing on different aspects of the relation between innovation and public administrations in Speyer and at Berlin Technical University. Since 2010 he is working as senior researcher at Fraunhofer FOKUS. Currently his research focuses on the identification and assessment of trends and future action field in public IT. 
Determinants of Public Sector Innovation: The Example of Capacity Development in Public Procurement

\section{References}

Audet, D. (2002). Government Procurement: A Synthesis Report. OECD Journal on Budgeting 2(3), 149-194. DOI: 10.1787/budget-v2-art18-en

Audretsch, D. B., Keilbach, M. C., \& Lehmann, E. E. (2006). Entrepreneurship and Economic Growth. New York. DOI: 10.1093/acprof:oso/9780195183511.001.0001

Beard, R. T., Ford, G. S., Koutsky, T. M., \& Spiwak, L. J. (2009). A Valley of Death in the Innovation Sequence: An Economic Investigation. Research Evaluation, 18(5), 343-356. DOI: $10.3152 / 095820209 \times 481057$

Beckenbach, F., \& Daskalakis, M. (2010). Invention und Innovation als kreative Problemlösungsprozesse. In M. Moldaschl, \& N. Stehr (Eds.), Wissensökonomie und Innovation (pp. 259-292). Marburg.

Blind, K., \& Weber, M. (2012). Normierte Kreativität? Die Bedeutung von Normen im öffentlichen Einkauf. In D. Hilgers, R. Schaver \& Thom, N. (Eds.), Staat und Verwaltung im Spannungsfeld von New Public Management, Open Government und bürokratischer Restauration (pp. 585-600). Linz: Tauner.

Boldrin, M., \& Levine, D. K. (2013). The Case against Patents. Journal of Economic Perspectives, 27(1), 3-22. DOI: 10.1257/jep.27.1.3

Brandstätter, H. (1992). Anthropologisch-psychologische Aspekte einer evolutionären Ökonomik. In: B. Biervert \&, M. Held (Eds.), Evolutorische Ökonomik. Normen, Institutionen, Neuerungen (pp. 92-109). Frankfurt.

Edler, J. et al. (2005). Innovation and Public Procurement. Review of Issues at Stake. Study for the European Commission (No ENTR/03/24). Final Report. Karlsruhe: Fraunhofer ISI.

Edquist, C. (1997). Systems of Innovation Approaches - their Emergence and Characteristics. In C. Edquist (Ed.). Systems of Innovation: Technologies, Institutions and Organizations (pp. 1-35). London.

Edquist, C. (2001). The Systems of Innovation Approach and Innovation Policy: An Account of the State of the Art. Lead Paper presented at the DRUID conference, Aalborg, June 12-15, 2001. Retrieved 28. 1. 2015, from http:// citeseerx.ist.psu.edu/viewdoc/download?doi=10.1.1.336.4438\&rep=rep1\&type= $\mathrm{pdf}$

Edquist, C. (2002). Innovation Policy - A Systematic Approach. In B. A. Lundvall \& D. Archibugi (Eds.), The Globalizing Learning Economy (pp. 219-238). Oxford. DOI: $10.1093 / 0199258171.003 .0013$

Edquist, C., Hommen, L., \& Tsipouri, L. (2000). Public technology procurement and innovation. Economics of science, technology and innovation, Vol. 16. Dordrecht: Kluwer. DOI: 10.1007/978-1-4615-4611-5

Edquist, C., \& Zabala-Iturriagagoitia, J.M. (2012). Public Procurement for Innovation as mission-oriented Innovation Policy. Research Policy, 41(10), 1757-1769. DOI: 10.1016/j.respol.2012.04.022

Elsner, W., \& Hanappi, H. (Eds.). (2008). Varieties of Capitalism and New Institutional Deals. Edward Elgar.

Etzkowitz, H., \& Leydesdorff, L. (2000). The Dynamics of Innovation: from National Systems and "Mode 2" to a Triple Helix of university-industrygovernment relations. Research Policy, 29(2), 109-123.

DOI: 10.1016/S0048-7333(99)00055-4 
European Commission. (2007a). Guide on Dealing with Innovative Solutions in Public Procurement. 10 Elements of Good Practice. PRO INNO Europe paper No 1. Luxembourg: European Communities.

European Commission. (2007b). Pre-commercial Procurement: Driving Innovation to Ensure Sustainable High Quality Pubic Services in Europe. Brussels.

European Commission. (2010). Risk management in the Procurement of innovation. Concepts and empirical evidence in the European Union. Luxembourg: Publications Office of the European Union.

European Commission (2011). Commission Staff Working Paper. Retrieved 3. 2. 2015, from http://ec.europa.eu/research/horizon2020/pdf/proposals/ horizon_2020_impact_assessment_report.pdf\#view=fit\&pagemode=none

Eurostat. (2010). Government statistics. Retrieved 19. 6. 2014, from http://epp. eurostat.ec.europa.eu/portal/page/portal/government_finance_statistics/data/ database

Fagerberg, J. (2003). Schumpeter and the Revival of Evolutionary Economics: An Appraisal of the Literature. Journal of Evolutionary Economics, 13(2), 125-159. DOI: $10.1007 / \mathrm{s} 00191-003-0144-1$

Fagerberg, J. (2006). Innovation. A Guide to the Literature. In J. Fagerberg, D. C. Mowery \& R. Nelson (Eds.), Oxford Handbook of Innovation (pp. 1-26). Oxford. DOI: 10.1093/oxfordhb/9780199286805.001.0001

Georghiou, L., Li, Y., Uyarra, E., \& Edler, J. (2010). Public Procurement for Innovation in Small European Countries. Retrieved 3. 2. 2025, from http:// ec.europa.eu/environment/gpp/pdf/Public\%20Procurement\%20for\%20 Innovation\%20in\%20Small\%20European\%20Countries.pdf

Goto, A. (2000). Japan's national innovation system: current status and problems. Oxford Review of Economic Policy, 16(2), 103-113.

DOI: $10.1093 /$ охгер/16.2.103

Greenhalgh, C., \& Rogers, M. (2010). Innovation, Intellectual Property, and Economic Growth. Princeton/Oxford.

Hagiu, A., \& Yoffie, D. B. (2013). The New Patent Intermediaries: Platforms, Defensive Aggregators, and Super-Aggregators. Journal of Economic Perspectives, 27(1), 45-66. DOI: 10.1257/jep.27.1.45

Hall, P. A., \& Soskice, D. (Eds.). (2001). Varieties of Capitalism: the Institutional Foundations of Comparative Advantage. Oxford.

Heckhausen, H. (1980). Motivation und Handeln. Berlin.

House of Commons. (2013). Bridging the Valley of Death: improving the commercialisation of research. Retrieved 3. 2. 2015, from http://www. publications.parliament.uk/pa/cm201213/cmselect/cmsctech/348/348.pdf

Hughes, A., Moore, K., \& Kataria, N. (2011). Innovation in the Public Sector: A Pilot Survey for Measuring Innovation across the Public Sector. NESTA report. Retrieved 3. 2. 2015, from http://www.nesta.org.uk/sites/default/files/ innovation_in_public_sector_orgs.pdf

ICLEI, et al. (2015). Procurement of Innovation Platform. Retrieved 10. 2. 2015, from http://www.innovation-procurement.org

Krone, H. G. (2003). Die Bedeutung der Verwaltungskultur. Eine Kulturanalyse zur Wirtschaftsförderungspolitik in der sächsischen öffentlichen Verwaltung. Osnabrück: Der andere Verlag.

Leydesdorff, L. (2010). The Triple Helix, Quadruple Helix, ..., and an N-tuple of Helices: Explanatory Models for Analyzing the Knowledge-based Economy? Retrieved 19. 6. 2014, from http://arxiv.org/abs/1012.1937 
Lorenz, O., et al. (2009). The 'Purchasing State' as a Driver of Innovation. Development potential and necessities relative to more-innovative procurement in Germany's public procurement sector. Final report. Berlin: Wegweiser.

Lundvall, B.-A. (1999). National Business Systems and National Systems of Innovation. International Studies of Management and Organization, 29(2), 60-77.

Moser, P. (2013). Patents and Innovation: Evidence from Economic History. Journal of Economic Perspectives, 27(1), 23-44. DOI: 10.1257/jep.27.1.23

Nelson, R. R. (1993). National Systems of Innovation: A Comparative Analysis. Oxford.

Osawa, Y., \& Miyazaki, K. (2006). An Empirical Analysis of the Valley of Death: Large-scale R\&D Project Performance in a Japanese Diversified Company. Asian Journal of Technology Innovation, 14(2), 93-116.

DOI: $10.1080 / 19761597.2006 .9668620$

Otter, N. (2009). Schumpeters Diagnose zu Wandel und Krisen im Kapitalismus. Berliner Debatte Initial, 20(4), 41-48.

Otter, N., Siegel, T., \& Weber, M. (2007). Der Vorrang der Öffentlichen Ausschreibung im Vergabewesen. Verwaltung und Management, 13(2), 94103.

Picot, A., \& Schneider, D. (1988). Unternehmerisches Innovationsverhalten, Verfügungsrechte und Transaktionskosten. In D. Budäus, E. Gerum, \&, G. Zimmermann (Eds.), Betriebswirtschaftslehre und Theorie der Verfügungsrechte (pp. 91-118). Wiesbaden. DOI: 10.1007/978-3-322-83718-9 5

Röpke, J. (1983). Handlungsrechte und wirtschaftliche Entwicklung. In A. Schüller (Ed.), Property Rights und ökonomische Theorie (pp. 111-144). München.

Röpke, J. (1987). Möglichkeiten und Grenzen der Steuerung wirtschaftlicher Entwicklung in komplexen Systemen. In M. Borchert, U. Fehl, \&, P. Oberender, Markt und Wettbewerb (pp. 227-243). Bern und Stuttgart.

Röpke, J. (2002). Der lernende Unternehmer. Norderstedt.

Siemon, C. (2009). Innovationspolitik, Wissenstransfer und der 6. Kondratieff: Knabenmorgenblütenträume in der Krise? Norderstedt.

Uyarra, E. (2010). Opportunities for Innovation through Local Government Procurement: A Case Study of Greater Manchester. NESTA research report. Retrieved 3. 2. 2015, from http://www.nesta.org.uk/sites/default/files/ opportunities_for_innovation_through_local_government_procurement.pdf

Weber, M. (2009). Procurement of innovation in Germany: political goals and empirical findings. Retrieved 19. 6. 2014, from http://www.oecd.org/ dataoecd/50/2/43726963.pdf

Weber, M. (2010). Die Bedeutung der Beschaffung für die öffentliche Wertschöpfung - eine empirische Annäherung. InfrastrukturRecht, 7(11), 323-327.

Zimmermann, H., Otter, N., Stahl, D., \& Wohltmann, M. (1998). Innovation jenseits des Marktes - Neuerungsverhalten in Staat, privaten Haushalten und Nonprofit Organisationen und der Einfluss umweltpolitischer Instrumente. Berlin. 
POVZETEK

\subsection{Originalni znanstveni članek}

\section{Determinante inovacij v javnem sektorju: primer razvoja zmogljivosti v javnih naročilih}

Ključne besede: inovacija, model trojne spirale, ekonomika javnega sektorja, razvoj zmogljivosti, javna naročila za inovacije

Glede na spoznanje, da so država in njeni organi v katerem koli inovacijskem sistemu pomembni dejavniki, raziskuje avtor inovativno aktivnost v javni upravi.

Članek na kratko predstavlja raziskave o inovativnosti, ki temeljijo nat. i. modelu trojne spirale (ang. Triple-Helix Model) in na nacionalnem sistemu pristopa k inovacijam. Model trojne spirale izhaja iz ideje, da bi uspešen nacionalni inovacijski sistem moral vključevati tri kompleksne družbene podsisteme in sicer: gospodarstvo zasebnega sektorja, državo in znanost. Model trojne spirale se namreč uporablja kot metafora za medsebojne povezave med temi sektorji. Opredeljuje značilnosti pripadajočih mrež, medtem ko na drugi strani poudarja razlike glede strukture spodbud in spremenljivosti. A kot je v razpravi o inovacijski sistemih pripomnil že Edquist (2001, str. 3), se slabost pristopa k inovacijskim sistemom kaže predvsem v pomanjkanju »teoretične« komponente o vlogi države.

To je pomembna pomanjkljivost, saj so država in njeni organi več kot očitno pomembne determinante inovacij v katerem koli inovacijskem sistemu. Zato Edquist predlaga, da bi se funkciji oziroma determinantam inovacij prisodilo več poudarka, kar bi pomembno razširilo teoretični pristop k inovacijskem sistemu. Tako bi povezali »konceptualno in teoretično delo z empiričnimi študijami, tako opredelili determinante in povečali znanje.«

$\checkmark$ skladu s tem je predlagani pristop mogoče razumeti kot dodaten okvir, ki omogoča pridobitev preverljivih trditev. Na osnovi zgodnjega dela Röpkeja (1977) so kot determinante inovativne dejavnosti uporabljene naslednje tri vrste spremenljivk: lastninske pravice, zmožnosti in motivacija. Na podlagi tega teoretičnega ozadja so bile ugotovljene možnosti in problemi inovativne dejavnosti, ki bi se lahko uresničile ali bi nastali v administraciji. Kot analitično orodje bi slednje lahko pomagalo pri prepoznavanju pomembnih posledic za delovanje inovacijskega sistema. Če zaposlenim v javni upravi ni dovoljeno oziroma ti niso zmožni ali motivirani za inovacije, potem strukturna povezava z drugimi sektorji (znanostjo in gospodarstvom) na dolgi rok ne bo uspešna.

Javna naročila za inovacije je mogoče šteti za vzoren primer inovativnih aktivnosti $v$ modelu trojne spirale. Pri nabavi se razmerje med vlado in gospodarstvom razširja z vidika raziskovanja in razvoja. V takšnih projektih 
sodelujejo vsi trije družbeni podsistemi, pri čemer znanost in gospodarstvo opravljata svojo specifično funkcijo proizvodnje znanja ali dobrin in storitev.

Še več, zaradi omenjenega medsebojnega odnosa nastajajo novi izzivi za javno upravo. Nabava inovacij zahteva ukrepe z odločno usmerjenostjo k inovacijam, kar pa pogosto ovira obstoječa zakonodaja, ki ureja javna naročila. Usmerjenost $k$ inovacijam pogosto spremlja tudi inovativno ravnanje s postopki (Lorenz in drugi, 2009, 64-75). Glede na te povezave, se inovativno vedenje razume v smislu zgoraj razvitega teoretičnega pristopa kot inovativna metoda obravnave, kot inovativno usmerjena praksa javnega naročanja in preprosto kot nabavna inovacija.

Zato javna naročila vsebujejo potencial precejšnje inovacijske spodbude tako za javno upravo in gospodarstvo, kot tudi za znanost. Glede na ta velikanski potencial, pregled usmerjenosti $v$ inovacije in stopnja inovativnosti nemške zvezne prakse javnega naročanja precej razočarata. Spodbujanje inovativnosti pri strategiji javnega naročanja ima zgolj podrejeno vlogo, pri čemer je za oddajo javnih naročil, namesto številnih gospodarskih sodil ključna nabavna cena. Prav zaradi tega je sprejem inovativnih rešitev malo verjeten (Weber, 2009).

Da bi pojasnili zgoraj navedeno vrzel med potencialno in dejansko prakso javnega naročanja, kot orodja za inovacije, odvisne od povpraševanja, članek podrobneje obravnava tri spremenljivke inovativnega vedenja. $V$ ta namen najprej izhaja iz hipoteze o pozitivnem vplivu petih dejavnikov iz analitičnega orodja, to so: okvirni pogoji, prevzemanje tveganja, posebno usposabljanje, organizacijska struktura in motivacija.

Z uporabo podatkov iz nemške prakse javnega naročanja lahko preverimo zgoraj navedene hipoteze. Statistični model zagotavlja empirični dokaz za hipoteze, da imajo okvirni pogoji, posebno usposabljanje in motiviranost zaposlenih na področju javnega naročanja precejšen pozitivni vpliv na inovativno vedenje pri javnih naročilih. Prav nasprotno pa pri hipotezah glede tveganja in organizacijske strukture ne moremo opaziti pomembnega vpliva. Vendar rezultati študije primera poudarjajo pomembnost vseh treh determinant inovativnega vedenja. Lastninske pravice (splošni pogoji), zmožnosti (posebno usposabljanje) in motivacija (spodbujanje) vplivajo na način dela javnih organov. Analitični okvir, razvit v tej raziskavi, pa omogoča boljše razumevanje dejstva, da je praksa naročanja inovativnih rešitev še vedno zelo omejena.

Skratka, številne ovire v delovanju in povezovanju organov javnega sektorja, pomanjkanje motivacijskih elementov v upravni kulturi in nasprotje med nizko ravnjo usposabljanja za javna naročila ter kompleksnostjo inovacijsko usmerjene prakse javnega naročanja, preprečujejo, da bi javno naročanje postalo instrument za spodbujanje inovativnosti javnih organov kot tudi zasebnih podjetij. Rezultati inovacijskega sistema bi lahko bili precejšnji: vendar če pomembnim akterjem ni dovoljeno inovirati, javni menedžerji pa niso zmožni ali niso motivirani za inoviranje, potem se vlada in gospodarski sistem pri tej nalogi še dolgo ne bosta uspešno povezala. 